Asian J. Med. Biol. Res. 2019, 5 (1), 78-86; doi: 10.3329/ajmbr.v5i1.41049

\author{
Asian Journal of \\ Medical and Biological Research \\ ISSN 2411-4472 (Print) 2412-5571 (Online) \\ www.ebupress.com/journal/ajmbr
}

\title{
Article \\ Effects of aspirin on aquaponics tomato (Solanumly copersicum) production in laboratory condition
}

\author{
Alif Layla Bablee, K. M. Shakil Rana ${ }^{*}$ and M. A. Salam \\ Department of Aquaculture, Bangladesh Agricultural University, Mymensingh-2202, Bangladesh \\ *Corresponding author: K. M. Shakil Rana, Department of Aquaculture, Bangladesh Agricultural University, \\ Mymensingh-2202, Bangladesh. Phone: +8801728300299; E-mail: ranakms@bau.edu.bd
}

Received: 06 March 2019/Accepted: 28 March 2019/ Published: 31 March 2019

\begin{abstract}
The experiment was conducted to visualize the effect of exogenous aspirin on tomato production in aquaponic system. Aspirin, a derivative of salicylic acid, acts as a potential non-enzymatic antioxidant and plant growth promoter, hence regulates plant physiology. The experiment employed three treatments $(\mathrm{T})$ with three replications (R) each where, $60 \mathrm{ppm}$ and $120 \mathrm{ppm}$ aspirin were used in $\mathrm{T}_{1}$ and $\mathrm{T}_{2}$, respectively and $\mathrm{T}_{\text {con }}$ was control with no aspirin. Media filled plastic containers $(0.29 \mathrm{~m} \times 0.30 \mathrm{~m} \times 0.21 \mathrm{~m})$ as growbeds and plastic tanks of 120 liter capacity as fish tank were installed to construct each aquaponic systems indicating each replication. Tilapia, was stocked at 111 fish $/ \mathrm{m}^{3}$ in the fish tank and fed commercial floating feed containing $30 \%$ protein at the rate of $3 \%$ body weight twice daily. In each replication, two tomato saplings were planted. Fish tank water was oxygenated with a 10 watt air pump, then waste water from tank was pumped to grow bed with a 12 watt submersible pump. Survival rates were 70,85 and $50 \%$ in $\mathrm{T}_{1}, \mathrm{~T}_{2}$ and $\mathrm{T}_{\text {con }}$ respectively. While fish productions were $0.42,0.34$ and $40.49\left(\mathrm{~kg} / \mathrm{m}^{2} / 60\right.$ days) in $\mathrm{T}_{1}, \mathrm{~T}_{2}$ and $\mathrm{T}_{\text {con }}$ respectively. The water quality parameters were within the suitable ranges for tilapia as well as tomato in the aquaponic system. Foliar spray of aspirin was applied fortnightly. Tomato production was hampered with various diseases in all the treatments although the aspirin treated plant $\left(T_{1}\right.$ and $\left.T_{2}\right)$ were free from few diseases. The highest tomato production was found 0.44 $\mathrm{kg} / \mathrm{m}^{2} / 60$ days in $T_{2}$ followed by $T_{1}\left(0.42 \mathrm{~kg} / \mathrm{m}^{2} / 60\right.$ days $)$ and $T_{\text {con }}\left(0.34 \mathrm{~kg} / \mathrm{m}^{2} / 60\right.$ days $)$. Noticeably, Plant growth and tomato production were higher in $T_{2}$ and $T_{1}$ with less disease prevalence than $T_{\text {con }}$, suggesting positive impacts of aspirin on tomato. However, further research is needed to justify the aspirin doses at user level.
\end{abstract}

Keywords: aquaponics; aspirin; foliar application; tomato

\section{Introduction}

Tomato as one of the most widely produced and consumed vegetable in the world (Heuvelink, 2005), contains high levels of antioxidant active compounds such as vitamin C, polyphenols and carotenoids (Tommonaro et al., 2012). Tomato is known as the nutritional powerhouse for human being, containing low-calorie (just 18 calories per $100 \mathrm{~g}$ ), and low in fat contents and have zero cholesterol levels. However, tomato in aquaponic system or in conventional systems sometimes get affected by diseases due to lack of hormones and reduce the production. Salicylic acid (SA) act as a potential non-enzymative antioxidant as much as plant growth regulator, playing an important role in regulating a number of plant physiological processes (Fariduddin et al., 2003; Raskin, 1992). Aspirin or Acetylsalicylic Acid (ASA) is one of the derivatives of Salicylic acid (SA), is a medicine properties normally used to treat human diseases. It triggers plant's defenses against disease, protect the plants from fungal, bacterial and viral infections. ASA behaves like a hormone and acts as a growth promoter in plants. Salicylic acid, acetylsalicylic acid or other analogues of SA can function as a plant hormones (Pallag et al., 2014). SA is an important mediator of the plant defense response to pathogens (White, 1979). Exogenously supplied SA was shown to affect a large variety of processes in plants, including stomatal closure, seed 
germination, fruit yield and glycolysis (Cutt and Klessing, 1992). The first indication for a physiological effect of SA was the discovery of flower-inducing action and bud formation in tobacco cell cultures (Eberhard et al., 1989). The stimulatory effect of SA on flowering was latter demonstrated in other plant species and this was ground for suggesting that SA functions as an endogenous regulator of flowering (Cleland and Ajami, 1974). Singh and Kaur (1981) stated that foliar application of SA (100 ppm) on baby corn increased the plant height, leaf area, crop growth rate and total dry matter production. On the other hand, aquaponics, as a closed loop system consisting of hydroponics and aquaculture elements, is increasingly practiced in many parts of the world (Goddek et al., 2015). It is the perfect engineering of ecology, is the combination of aquaculture (fish or crustaceans) and hydroponic cultivation of plants (hydroponic vegetables, flower, and/or herb) in a recirculating system, utilizing the nutrients present in the aquaculture effluents to produce plants with commercial value (Gollardo-Colli et al., 2014; Yildiz et al., 2017). Intensive re-circulating aquaponic system reused relatively small volumes of water by circulating through bio-filters to remove toxic waste products before returning the water to production tanks. The system allowed production of fish much higher than in extensive pond culture with carrying capacity $\mathrm{kgm}^{-3}$ and $0.6 \mathrm{kgm}^{-3}$ respectively (Losordo et al., 1998). Therefore, the present experiment was conducted to increase the tomato production, reduce the prevalence of diseases and improve the nutritional quality of tomato by using foliar application of aspirin.

\section{Materials and Methods}

\subsection{Site selection}

The experiment was carried out at the aquaponics laboratory of the faculty of Fisheries in the Bangladesh Agricultural University (BAU), Mymensingh. The laboratory was well protected and had good locked door system. Besides, it is a clean and dry place. The experimental set up was in well exposed to sunlight.

\subsection{Experimental design}

The duration of the experiment was 60 days from $19^{\text {th }}$ March to $18^{\text {th }}$ May, 2018. Among different types of aquaponic system, media based system was selected to conduct the experiment. The experimental design was comprised of nine fish holding tanks, each containing 90 liter of water and nine plastic containers for vegetable growing bed. Those were cut longitudinally 0.5 inch below the upper surface to make it a bed. These containers were randomly allocated as treatments $T_{1}, T_{2}$ and control. Each treatment and control were have three replications $\left(R_{1}, R_{2}\right.$ and $\left.R_{3}\right)$ and these were denoted as $T_{1} R_{1}, T_{1} R_{2}, T_{1} R_{3}, T_{2} R_{1}, T_{2} R_{2}, T_{2} R_{3}, T_{\text {Con }} R_{1}, T_{\text {Con }} R_{2}$, $\mathrm{T}_{\mathrm{Con}} \mathrm{R}_{3}$ (Figure 1). For oxygenation, an air pump of 18 watt with one air stone was added in each fish tank. The water from the fish tank was irrigated to the tomato bed by a 12 watt submersible pump.

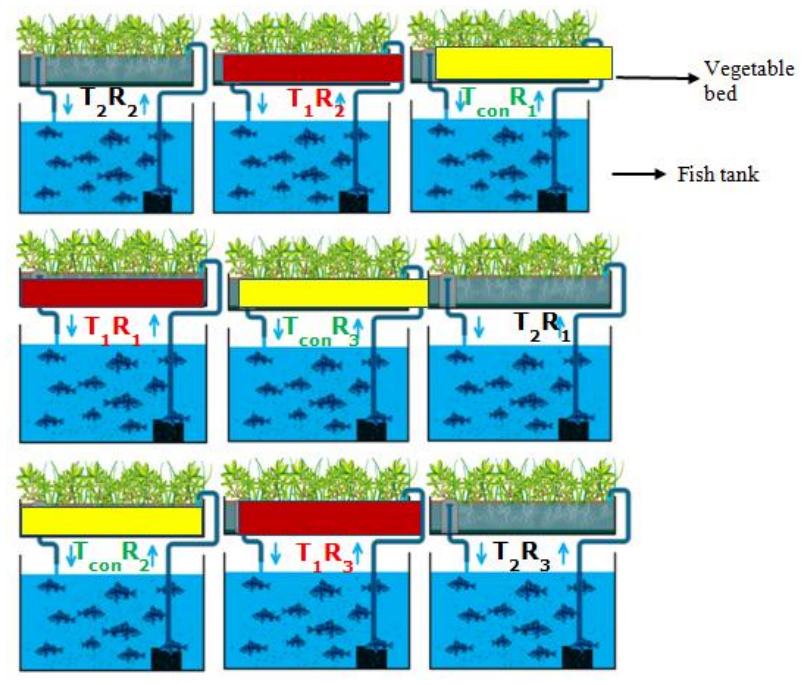

Figure 1. Experimental layout of aquaponic systems.

\subsection{Stocking and rearing the fish}

Monosex tilapia fingerlings were bought from the local renowned hatchery. After acclimatization they were stocked in the tank at the density of 10 fingerlings/90 liter tank. A 12 watt submersible water pump was added in each tank to lift up waste water from fish tank to vegetable bed from 9:00 am to 5:00 pm. One aerator along with one air stone was set in each tank to facilitate dissolve oxygen to prevent oxygen deficiency in the tank 
water. The fish was fed with commercial floating feed containing 30\% protein twice (10.00 am and 4:00 pm) daily at the rate of $3 \%$ body weight.

\subsection{Bed preparation for tomato cultivation}

Locally available, cheap, good quality plastic container was used as tomato culture bed. Nine plastic container were bought from local market. The size of each container was $0.29 \mathrm{~m} \times 0.30 \mathrm{~m} \times 0.21 \mathrm{~m}$. Those were cleaned with detergent, rinsed with clean water for 3 to 4 times and sun dried before use. Those were cut longitudinally 0.5 inch below from the upper surface with a sharp knife to make it a bed. One pore was made above 0.5 inch from the bottom of each container to connect outlet pipe with $\mathrm{m}$-seal to facilitate clean water from the tomato bed to the fish tank after filtering. A PVC plastic pipe (length $0.27 \mathrm{~m}$ and diameter $0.12 \mathrm{~m}$ ) was used as siphon in each bed by making pores in it. Plastic containers were set on wooden structure.

\subsection{Fish and vegetable sampling}

Fish and vegetable were sampled fortnightly. The number of bunches, flowers and fruits were counted and plant height was measured fortnightly during the study period. The ripe tomato was weighed and recorded during harvesting. During each sampling, all fishes were caught from each replication with scoop net and individual length-weight was measured with an electronic compact balance (EK-600i) and wooden fish length measuring scale.

\subsection{Fish and vegetable harvesting}

After 90 days all the fish were harvested and their growth Performance was measured such as length gain $(\mathrm{cm})$, weight gain (g), percent weight gain, food conversion ratio (FCR), survival rate (\%) and fish production $\left(\mathrm{kg} / \mathrm{m}^{2}\right)$. Ripen tomato was harvested and weighed up to the experiment completion. After final harvesting roots were picked up from the beds and washed carefully with tap water. Both the roots and plants were weighed by using electric balance.

\subsection{Physico chemical parameter of fish tank water measurement}

Physico chemical parameters of tank water were measured to know the suitability of fish culture. Temperature and $\mathrm{pH}$ were measured every 7 days interval. Electric conductivity (EC), Carbonate $\left(\mathrm{CO}_{3}\right)$, Hydrogen carbonate $\left(\mathrm{HCO}_{3}\right)$, Potassium $(\mathrm{K})$, Total nitrogen $(\mathrm{N})$, Sulphur $(\mathrm{S})$ and Sodium $(\mathrm{Na})$ were measured three times interval during experiments. The tests were done in the Humboldt Soil Testing Laboratory, Soil Science department, Bangladesh Agricultural University.

\subsection{Data processing and analysis}

The collected data were entered in MS Excel 2010 and significant differences between treatments were tested employing ANOVA (one-way analysis of variance) using statistical software SPSS-20 and Duncan's New Multiple Range Test (DMRT).

\section{Results and Discussion}

\subsection{Plant growth performance}

The highest mean leaf number, flower number and bunch number of tomato plant were found $48.5 \pm 12.5$, $19.00 \pm 3.60,5.33 \pm 0.57$ in $T_{1}$. Whereas the lowest mean leaf number, flower number and bunch number were $34.5 \pm 1,0.76 \pm 0.5$ and $5 \pm 5$ recorded in $\mathrm{T}_{\text {con. }}$. The highest mean leaf area was $21.61 \pm 2.6 \mathrm{~cm}^{2}$ in $\mathrm{T}_{1}$ followed by $\mathrm{T}_{2}$ $\left(15.83 \pm 2.69 \mathrm{~cm}^{2}\right)$ and $\mathrm{T}_{\text {con }}\left(14.79 \pm 0.32 \mathrm{~cm}^{2}\right.$ ) (Figure 2). These might be due to the presence of aspirin (a derivative of SA) in the treatments that function as an endogenous regulator of flowering (Cleland and Ajami, 1974). According to Singh and Kaur (1981), foliar application of SA (100 ppm) on baby corn increased the plant height, leaf area, crop growth rate and total dry matter production that conform to the present findings. Plant heights were measured fortnightly. The highest mean height of the plant was $286.0 \pm 64.00 \mathrm{~cm}$ in $T_{1}$ at the end of experiment which was higher than the findings of Cole et al. (2016). At the same time the plant height in $\mathrm{T}_{2}$ was $231.75 \pm 36.75 \mathrm{~cm}$ whereas, the lowest mean height of the plant was $167.50 \pm 23.00 \mathrm{~cm}$ in $\mathrm{T}_{\text {con. }}$. There was significant difference in mean height of plant among the three treatments on different dates (Figure 3). Total plant weight, Root length and weight were calculated after harvesting on $18^{\text {th }}$ May 2018. The highest mean weight of plant was $178.75 \pm 100.23 \mathrm{~g}$ in $\mathrm{T}_{2}$ whereas $147.92 \pm 96.17 \mathrm{~g}$ was found in $\mathrm{T}_{1}$ and $136.34 \pm 43.18 \mathrm{~g}$ in $\mathrm{T}_{\text {con }}$ (Table 1). The highest mean length and weight of root $42.50 \pm 5.13 \mathrm{~cm}$ and $94.47 \pm 134.49 \mathrm{~g}$ was obtained from $\mathrm{T}_{1}$. In contrast, the length and weight of $\mathrm{T}_{2}$ and $\mathrm{T}_{\text {con }}$ were $39.52 \pm 4.87 \mathrm{~cm}, 12.89 \pm 0.40 \mathrm{~g}$ and $29.83 \pm 8.04 \mathrm{~cm}$, $11.29 \pm 4.57 \mathrm{~g}$, respectively. There was no significant difference in mean length and weight among the treatments 
(Table 1). The highest fruit numbers were counted $15.33 \pm 0.57$ in $T_{1}$ and the lowest number were found in $T_{2}$. Though the fruit numbers were little bit higher in $T_{1}$ but the total fruits weight were significantly higher in $T_{2}$ than $\mathrm{T}_{1}$ and $\mathrm{T}_{\text {con }}$. All these ascertained the positive attributes of aspirin in the treatments although most suitable concentration of aspirin was ambiguous.

Table 1. Growth parameters of plant in different treatments at harvesting date.

\begin{tabular}{|c|c|c|c|c|c|}
\hline Sampling date & Parameter & $\begin{array}{l}\mathrm{T}_{1} \\
\text { Mean }( \pm \mathrm{SD})\end{array}$ & $\begin{array}{l}\mathbf{T}_{2} \\
\text { Mean }( \pm \text { SD })\end{array}$ & $\begin{array}{l}\mathbf{T}_{\text {con }} \\
\text { Mean }( \pm \text { SD })\end{array}$ & $\begin{array}{l}\text { Level of } \\
\text { significance }\end{array}$ \\
\hline \multirow{5}{*}{$18 / 5 / 2018$} & Plant wt. (g) & $147.92 \pm 96.17$ & $178.75 \pm 100.23$ & $136.34 \pm 43.18$ & $\mathrm{NS}$ \\
\hline & Root length $(\mathrm{cm})$ & $42.50 \pm 5.1$ & $39.52 \pm 4.8$ & $29.83 \pm 8.04$ & NS \\
\hline & Root wt. (g) & $94.47 \pm 134.48$ & $12.89 \pm 0.40$ & $11.29 \pm 4.57$ & NS \\
\hline & Fruits number & $15.33 \pm 0.58^{\mathrm{a}}$ & $9.0 \pm 1.0^{\mathrm{b}}$ & $9.33 \pm 0.58^{\mathrm{b}}$ & $* *$ \\
\hline & Total fruits wt. (g) & $46.35 \pm 6.8^{\mathrm{ab}}$ & $48.6 \pm 4.24^{\mathrm{a}}$ & $37.26 \pm 0.86^{\mathrm{c}}$ & $*$ \\
\hline
\end{tabular}

Note: Values are mean \pm Standard deviation from triplicate group. $\mathrm{T}_{1}=$ Treatment $1\left(60 \mathrm{ppm}\right.$ aspirin), $\mathrm{T}_{2}=$ Treatment $2(120$ ppm aspirin), $\mathrm{T}_{\text {con }}=$ Control (No aspirin). Values in a row having similar letters (s) or without letters do not differ significantly whereas values bearing the dissimilar letter (s) differ significantly as per DMRT (Duncan's New Multiple Range Test).

** Significant at $\mathrm{P} \leq 0.01 ; *$ significant at $\mathrm{P} \leq 0.05$; NS non-significant at $\mathrm{P}>0.05$

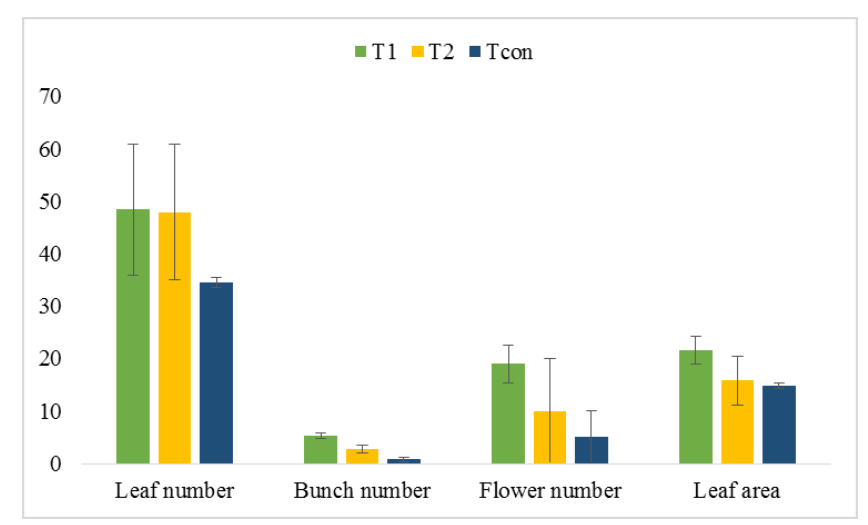

Figure 2. Mean leaf number, Bunch number, Flower number and leaf area $(\mathrm{cm} \pm \mathrm{SD})$ of salicylic acid treated $\left(T_{1}\right.$ and $\left.T_{2}\right)$ and non-treated ( $\left.T_{\text {con }}\right)$ tomato plants during experimental period in aquaponic system. Vertical bar of each treatment represents standard deviation $( \pm \mathrm{SD})$.

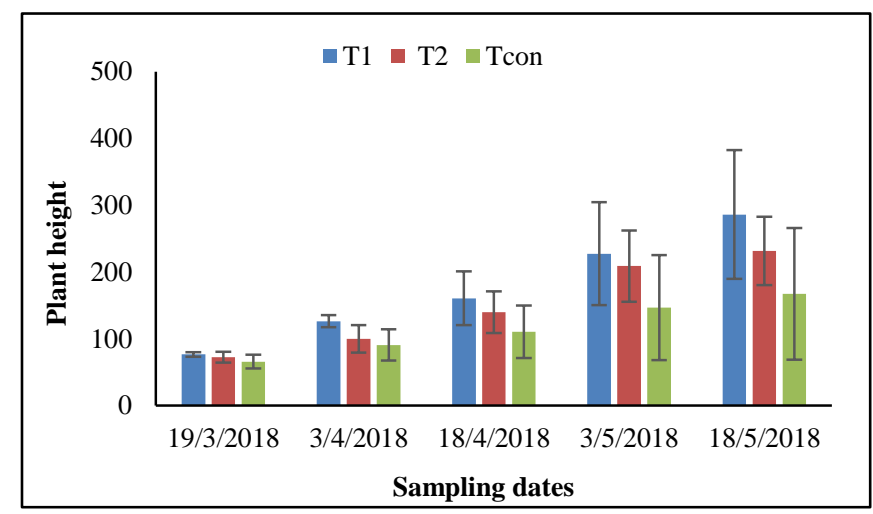

Figure 3. Height $(\mathrm{cm} \pm \mathrm{SD})$ of salicylic acid treated $\left(\mathrm{T}_{1}\right.$ and $\left.\mathrm{T}_{2}\right)$ and non-treated $\left(\mathrm{T}_{\mathrm{con}}\right)$ tomato plants at different sampling dates in aquaponic system. Vertical bar of each treatment represents standard deviation $( \pm \mathrm{SD})$.

\subsection{Tomato production}

The highest production was $0.44 \mathrm{~kg} / \mathrm{m}^{2} / 90$ days in $\mathrm{T}_{2}$ where tomato plants were treated with $60 \mathrm{ppm}$ aspirin (Figure 4). In the other treatments, these were $0.42 \mathrm{~kg} / \mathrm{m}^{2} / 90$ days $\left(\mathrm{T}_{1}\right)$ and $0.34 \mathrm{~kg} / \mathrm{m}^{2} / 90$ days $\left(\mathrm{T}_{\text {con }}\right)$. According 
to USDA (2019), the proximate composition of tomato was estimated as moisture $94.52 \%$, ash $0.53 \%$, crude fiber $1.2 \%$, crude protein $0.88 \%$, crude fat $0.20 \%$ and carbohydrate $3.89 \%$. Amount of protein and crude fiber content were higher but the carbohydrate content was lower than the aforementioned reference. Although, other nutrients' contents were nearly similar. The highest amount of lipid and fiber were found $0.87 \pm 0.01 \%$ and $3.20 \pm 0.1 \%$ in $\mathrm{T}_{1}$. The highest moisture content was $94.35 \pm 1.0 \%$ in $\mathrm{T}_{2}$ and the highest mean protein, ash and carbohydrate were $1.25 \pm 0.01 \%, 0.567 \pm 0.001 \%$ and $1.09 \pm 0.001 \%$ in $\mathrm{T}_{\text {con }}$ (Table 2). Therefore, the use of aspirin increased the moisture content but decreased the nutritional value of experimental tomato.

Table 2. Proximate composition (\% moisture basis) of tomato found at different treatments.

\begin{tabular}{lllllll}
\hline Treatment & $\begin{array}{l}\text { Protein } \\
\text { Mean } \pm \text { SD }\end{array}$ & $\begin{array}{l}\text { Lipid } \\
\text { Mean } \pm \text { SD }\end{array}$ & $\begin{array}{l}\text { Ash } \\
\text { Mean } \pm \text { SD }\end{array}$ & $\begin{array}{l}\text { Crude fiber } \\
\text { Mean } \pm \text { SD }\end{array}$ & $\begin{array}{l}\text { NFE } \\
\text { Mean } \pm \text { SD }\end{array}$ & $\begin{array}{l}\text { Moisture } \\
\text { Mean } \pm \text { SD }\end{array}$ \\
\hline $\mathrm{T}_{1}$ & $0.99 \pm 0.001^{\mathrm{c}}$ & $0.87 \pm 0.01^{\mathrm{a}}$ & $0.517 \pm 0.001^{\mathrm{b}}$ & $3.20 \pm 0.1^{\mathrm{a}}$ & $0.16 \pm 0.001^{\mathrm{b}}$ & $94.24 \pm 0.99$ \\
$\mathrm{~T}_{2}$ & $1.05 \pm 0.01^{\mathrm{b}}$ & $0.84 \pm 0.01^{\mathrm{b}}$ & $0.511 \pm 0.001^{\mathrm{c}}$ & $2.94 \pm 0.01^{\mathrm{b}}$ & $0.308 \pm 0.001^{\mathrm{a}}$ & $94.35 \pm 1.0$ \\
$\mathrm{~T}_{\text {con }}$ & $1.25 \pm 0.01^{\mathrm{a}}$ & $0.76 \pm 0.01^{\mathrm{c}}$ & $0.567 \pm 0.001^{\mathrm{a}}$ & $2.60 \pm 0.1^{\mathrm{c}}$ & $1.09 \pm 0.001^{\mathrm{c}}$ & $93.72 \pm 0.99$ \\
$\begin{array}{l}\text { Level of } \\
\text { significance }\end{array}$ & $* *$ & $* *$ & $* *$ & $* *$ & $* *$ & NS \\
\hline
\end{tabular}

Note: Values are given with $\left( \pm\right.$ Standard deviation). $T_{1}=$ Treatment $1(60 \mathrm{ppm}$ aspirin $), \mathrm{T}_{2}=$ Treatment $2(120 \mathrm{ppm}$ aspirin $)$, $\mathrm{T}_{\text {con }}=$ Control (No aspirin). Values in a column having similar letters (s) or without letters do not differ significantly whereas values bearing the dissimilar letter (s) differ significantly as per DMRT (Duncan's New Multiple Range Test).

** Significant at $\mathrm{P} \leq 0.01$; * significant at $\mathrm{P} \leq 0.05$; NS non-significant at $\mathrm{P}>0.01$

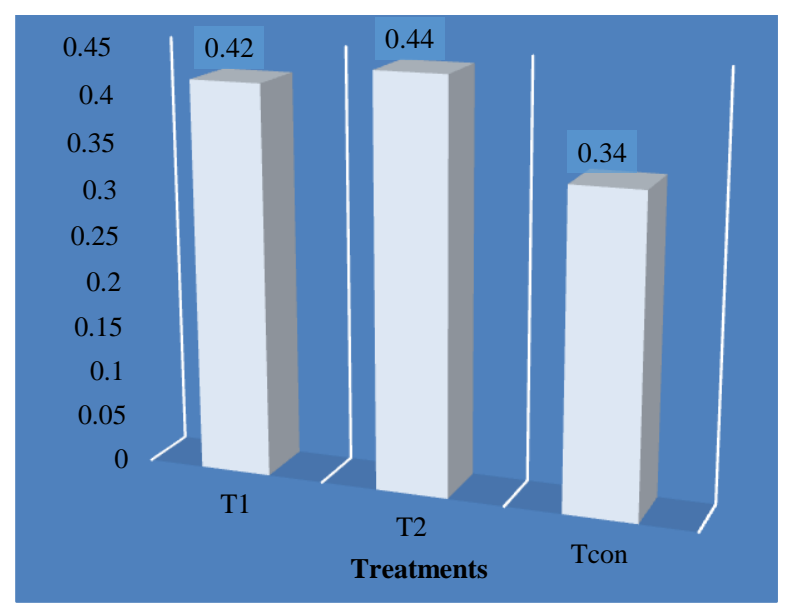

Figure 4. Total production of tomato $\left(\mathrm{kg} / \mathrm{m}^{2} / 60\right.$ days) from aspirin treated $\left(T_{1}\right.$ and $\left.T_{2}\right)$ and non-treated $\left(T_{\text {con }}\right)$ tomato plants after final harvesting. Vertical bar of each treatment represents standard deviation $( \pm$ SD).

\subsection{Plant health}

Leaf miners, blossom-end rot, cracking diseases and cutworms were found in $\mathrm{T}_{1}, \mathrm{~T}_{2}$ and $\mathrm{T}_{\text {con }}$. In addition TMV (Tobacco Mosaic Virus) and bacterial spot diseases were also found in $\mathrm{T}_{\text {con }}$. According to Fuentes et al. (2016) symptoms of leaf miners producing pest are shown in a specific way on the leaf surface. The damage is visualize as a tubular leaf puncture or a fan-shaped leaf puncture with irregular mines. Several leaf miners can be found even in the same leaf or plant. Blossom-end rot disease occur due to calcium deficiency. Tomato cracking diseases may occur due to excessive moisture, fluctuations in temperature, and an overabundance of nitrogen. According to Vlot et al. (2009) the plant hormone SA plays a major role in disease resistance signaling. Glazebrook (2005) reported that the SA response pathway is typically (but not exclusively) effective against microbial biotrophic pathogens. In previous experiment it is found that SAs ability to induce acquired resistance is not restricted to tobacco and TMV, but is effective in many plants against various necrotizing and systemic viral, fungal, and bacterial pathogens. However, it should be noted that not all plant-pathogen systems respond to SA (Pennazio et al., 1985; Roggero and Pennazio, 1988). SA also induces various PR proteins in a broad range of both dicotyledonous and monocotyledonous plants including tomato (White et al., 1987), potato (White et al., 1983), bean (Hooft et al., 1986). Losanka et al. (1997) reported that salicylic acid (SA) influence on different physiological processes. It has role on plant growth and development, flowering, ion uptake, 
stomatal regulation and photosynthesis. SA also act as a natural inducer of thermogenesis and disease resistance in plants.

\subsection{Fish growth performance}

Tilapia was reared for 90 days from $19^{\text {th }}$ March to $18^{\text {th }}$ May. The initial mean length of the fish were $13.62 \pm 0.05,12.03 \pm 0.20$ and $12.8 \pm 1.46 \mathrm{~cm}$ which were increased to $16.56 \pm 0.001$, and $15.51 \pm .36$ and $15.93 \pm 1.08 \mathrm{~cm}$ in $\mathrm{T}_{1}, \mathrm{~T}_{2}$ and $\mathrm{T}_{\text {con }}$ respectively and the mean initial weight were $53.16 \pm 2.05,34.34 \pm 2.69$ and $41.05 \pm 1.46 \mathrm{~g}$ that increased to83.27 $\pm 1.24,65.35 \pm 5.0$ and $76.56 \pm 3.27 \mathrm{~g}$ in $\mathrm{T}_{1}, \mathrm{~T}_{2}$ and $\mathrm{T}_{\text {con }}$ respectively. After a certain stage, tilapia length gain was slower compared to the weight increment (Figure 5). There was no significant difference among fish length and weight in different sampling dates. That might be due to small experimental unit. The length and weight gain, percent length gain, percent weight gain and Specific growth rate (\%/day) were lower but the survival rates were higher than the previous observation (Zahan et al., 2018). The FCR for tilapia in the present experiment was bit higher 3.05, 3.38 and 3.19 in $T_{1}, T_{2}$ and $T_{\text {con }}$ respectively than the findings of Rahmatullah et al. (2010) and Quagrainie et al. (2011) which were 2.69 and 3.1, respectively. The productions of tilapia were $0.42,0.34$ and $0.49 \mathrm{~kg} / \mathrm{m}^{2} / 90$ days in $\mathrm{T}_{1}, \mathrm{~T}_{2}$ and $\mathrm{T}_{\text {con }}$ respectively. There was no significant difference among the treatments (Table 3) although the productions were comparatively lower, which might be attributed to high stocking density. Notably, there was no impact of aspirin on fish growth. As before spraying aspirin to the tomato leaves water pumps were kept stopped, tomato beds were covered with polythene bags so that the aspirin solution could not mix to the water of fish tank.

Table 3. Growth performances of tilapia observed in different treatments during the study period.

\begin{tabular}{|c|c|c|c|c|}
\hline Parameters & $\mathbf{T}_{1}$ & $\mathbf{T}_{2}$ & $\mathbf{T}_{\text {con }}$ & Level of significance \\
\hline Mean Initial Length (cm) & $13.62 \pm .05$ & $12.03 \pm 0.20$ & $12.8 \pm 1.46$ & $\mathrm{NS}$ \\
\hline Mean Final Length (cm) & $16.56 \pm 0.001$ & $15.51 \pm .36$ & $15.93 \pm 1.08$ & NS \\
\hline Mean Length Gain (cm) & $2.94 \pm 0.05$ & $3.48 \pm 0.56$ & $3.12 \pm 1.18$ & NS \\
\hline Percent Length Gain (\%) & $21.56 \pm 0.45$ & $28.98 \pm 5.112$ & $25.18 \pm 12.22$ & NS \\
\hline Mean Initial Weight (g) & $53.16 \pm 2.05^{\mathrm{a}}$ & $34.34 \pm 2.69^{\mathrm{b}}$ & $41.05 \pm 1.46^{\mathrm{ab}}$ & $*$ \\
\hline Mean Final Weight (g) & $83.27 \pm 1.24^{\mathrm{a}}$ & $65.35 \pm 5.00^{\mathrm{b}}$ & $76.56 \pm 3.27^{\mathrm{a}}$ & $* *$ \\
\hline Mean Weight Gain (g) & $30.11 \pm 0.88$ & $31.02 \pm 7.69$ & $35.50 \pm 9.88$ & NS \\
\hline Percent Weight Gain (\%) & $56.74 \pm 3.73$ & $91.89 \pm 29.61$ & $95.85 \pm 53.65$ & NS \\
\hline Specific growth rate $(\%)$ & $0.749 \pm 0.04$ & $1.0729 \pm 0.26$ & $1.08 \pm 0.44$ & NS \\
\hline Survival Rate (\%) & $70 \%$ & $85 \%$ & $50 \%$ & - \\
\hline Feed Conversion Ratio & 3.05 & 3.38 & 3.19 & - \\
\hline Production $\left(\mathrm{kg} / \mathrm{m}^{2} / 60\right.$ days $)$ & 0.42 & 0.34 & 0.49 & - \\
\hline
\end{tabular}

Note: Values are given with \pm Standard deviation. T1= Treatment T1 (60 ppm aspirin), T2=Treatment T2 (120 ppm aspirin), Tcon=Control (No aspirin). Values in a row having similar letters (s) or without letters do not differ significantly whereas values bearing the dissimilar letter $(\mathrm{s})$ differ significantly $(\mathrm{P}<0.05)$ as per DMRT.

** Significant at $\mathrm{P} \leq 0.01$; significant at $\mathrm{P} \leq 0.05$; NS non-significant at $\mathrm{P}>0.01$

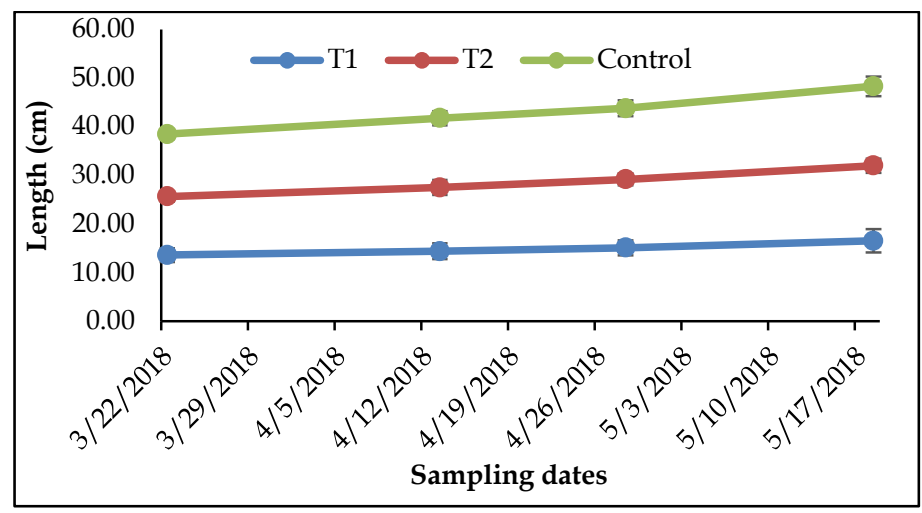

\section{A. Length gain of tilapia.}




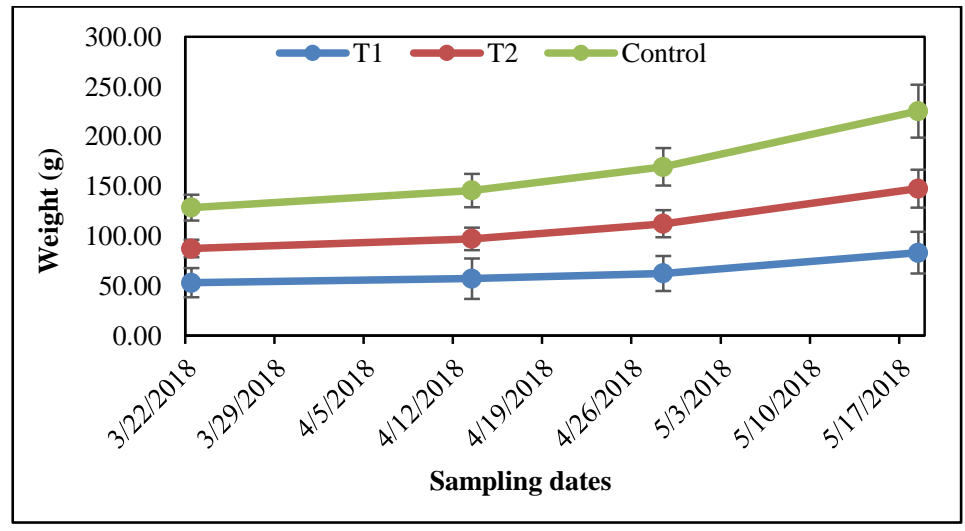

\section{B. Weight gain of tilapia.}

Figure 5. Growth pattern of fish in terms of length (A) and weight (B) gain during culture period.

\subsection{Water quality parameters}

The water quality parameters of the fish tanks were within the suitable range for aquaculture. As observed, the mean temperatures and $\mathrm{pH}$ values in fish tank water were $(26.1 \pm 0.75)^{\circ} \mathrm{C}$ and $6.92 \pm 0.13 ;(26.5 \pm 0.83)^{\circ} \mathrm{C}$ and $7 \pm 0.18$; and $(25.9 \pm 0.75)^{\circ} \mathrm{C}$ and $7.1 \pm 0.01$ in $\mathrm{T}_{1}, \mathrm{~T}_{2}$ and $\mathrm{T}_{\text {con }}$ respectively that was suitable for tilapia and tomato. In aquaponic system optimum temperature and $\mathrm{pH}$ for tilapia ranges from $28-32^{\circ} \mathrm{C}$ and $6.0-8.5$ respectively and for nitrifying bacteria ranges from $25-30^{\circ} \mathrm{C}$ and 7.0-8.0, respectively (Tyson and Simonne, 2014).The reported mean dissolved oxygen content (DO) of the tank water over the study period were $7.97 \pm 0.7,7.91 \pm 0.91$ and $7.92 \pm 0.7$ in $\mathrm{T}_{1}, \mathrm{~T}_{2}$ and $\mathrm{T}_{\text {con }}$ respectively (Figure 6). Highest electric conductivity (EC), hydrogen carbonate $\left(\mathrm{HCO}_{3}\right)$ and total Nitrogen $(\mathrm{N})$ were counted at $1388.5 \pm 26.27 \mu \mathrm{s} / \mathrm{cm}, 292.8 \pm 45.78$ and $11.45 \pm 1.76 \mathrm{mg} / 1$, respectively in $\mathrm{T}_{1}$ and the highest phosphorus $(\mathrm{P})$, Sulphur $(\mathrm{S})$ and Sodium $(\mathrm{Na})$ were found at $11.22 \pm 1.32$, $7.68 \pm 0.52$ and $163.88 \pm 8.6 \mathrm{mg} / \mathrm{l}$, respectively in $\mathrm{T}_{2}$ at the end of the experiment (Table 4). The highest Carbonate $\left(\mathrm{CO}_{3}\right)$ value was $24.0 \pm 13.86 \mathrm{mg} / \mathrm{l}$ in $\mathrm{T}_{1}$ at the middle of the study which was totally absent in the source water. The highest potassium (K) value was $13.12 \pm 2.33 \mathrm{mg} / \mathrm{l}$ in $\mathrm{T}_{\text {con }}$ at the end of the experiment (Table 4). There was no impact of aspirin on water quality parameter also.

Table 4. The water quality parameters of lab test results in different treatments during the experimental period.

\begin{tabular}{llllllll}
\hline \multirow{2}{*}{ Parameter } & \multirow{2}{*}{$\begin{array}{l}\text { Initial } \\
\text { data }\end{array}$} & \multicolumn{1}{c}{$\mathbf{T}_{\mathbf{1}}$} & \multicolumn{2}{c}{$\mathbf{T}_{\mathbf{2}}$} & \multicolumn{1}{c}{$\mathbf{T}_{\text {con }}$} \\
\cline { 3 - 8 } & $\mathbf{1 7 / 4 / 1 8}$ & $\mathbf{1 8 / 5 / 1 8}$ & $\mathbf{1 7 / 4 / 1 8}$ & $\mathbf{1 8 / 5 / 1 8}$ & $\mathbf{1 7 / 4 / 1 8}$ & $\mathbf{1 8 / 5 / 1 8}$ \\
\hline $\mathrm{EC}(\mu \mathrm{s} / \mathrm{cm})$ & 747 & $999.0 \pm 8.08$ & $1388.5 \pm 26.27$ & $990.0 \pm 8.37$ & $1352.0 \pm 72.75$ & $972.5 \pm 9.53$ & $1331.0 \pm 36.95$ \\
$\mathrm{CO}_{3}{ }^{-}(\mathrm{mg} / \mathrm{l})$ & 0 & $24.0 \pm 13.86$ & $0.00 \pm 0.00^{\mathrm{b}}$ & $33.0 \pm 5.19$ & $0.00 \pm 0.0^{\mathrm{b}}$ & $30.0 \pm 3.46$ & $9.00 \pm 3.0^{\mathrm{a}}$ \\
$\mathrm{HCO}_{3}^{-}(\mathrm{mg} / \mathrm{l})$ & 286.7 & $207.40 \pm 14.09$ & $292.8 \pm 45.78$ & $231.80 \pm 10.56$ & $265.35 \pm 8.80$ & $209.60 \pm 0.00$ & $240.95 \pm 12.33$ \\
$\mathrm{Total} \mathrm{N}(\mathrm{mg} / \mathrm{l})$ & 2.8 & $2.1 \pm 0.40$ & $11.45 \pm 1.76^{\mathrm{a}}$ & $0.7 \pm 0.40$ & $6.3 \pm 0.40^{\mathrm{b}}$ & $2.1 \pm 0.40$ & $6.3 \pm 0.40^{\mathrm{b}}$ \\
$\mathrm{P}(\mathrm{mg} / \mathrm{l})$ & 0.294 & $3.89 \pm 0.49^{\mathrm{b}}$ & $10.98 \pm 0.18$ & $4.87 \pm 0.26^{\mathrm{a}}$ & $11.22 \pm 1.32$ & $4.18 \pm 0.28^{\mathrm{ab}}$ & $9.05 \pm 0.31$ \\
$\mathrm{~K}(\mathrm{mg} / \mathrm{l})$ & 1.21 & $1.31 \pm 0.05$ & $5.55 \pm 0.40$ & $2.21 \pm 0.46$ & $12.51 \pm 3.85$ & $3.62 \pm 0.23$ & $13.12 \pm 2.33$ \\
$\mathrm{~S}(\mathrm{mg} / \mathrm{l})$ & 3.47 & $5.77 \pm 0.60$ & $6.82 \pm 0.15$ & $5.74 \pm 0.36$ & $7.68 \pm 0.52$ & $5.21 \pm 0.22$ & $6.56 \pm 0.13$ \\
$\mathrm{Na}(\mathrm{mg} / \mathrm{l})$ & 109.25 & $94.35 \pm 2.87^{\mathrm{a}}$ & $99.32 \pm 11.47^{\mathrm{b}}$ & $114.21 \pm 2.87^{\mathrm{b}}$ & $163.88 \pm 8.6^{\mathrm{a}}$ & $114.21 \pm 2.87^{\mathrm{b}}$ & $124.15 \pm 14.34^{\mathrm{ab}}$ \\
\hline
\end{tabular}

Note: Values are given with $\left( \pm\right.$ Standard error). $\mathrm{T}_{1}=$ Treatment 1 (60 ppm aspirin), $\mathrm{T}_{2}=$ Treatment 2 (120 ppm aspirin), $\mathrm{T}_{\text {con }}=$ Control (No aspirin). Values in a column having similar letters ( $\mathrm{s}$ ) or without letters do not differ significantly whereas values bearing the dissimilar letter $(\mathrm{s})$ differ significantly $(\mathrm{P}<0.05)$ as per DMRT. 


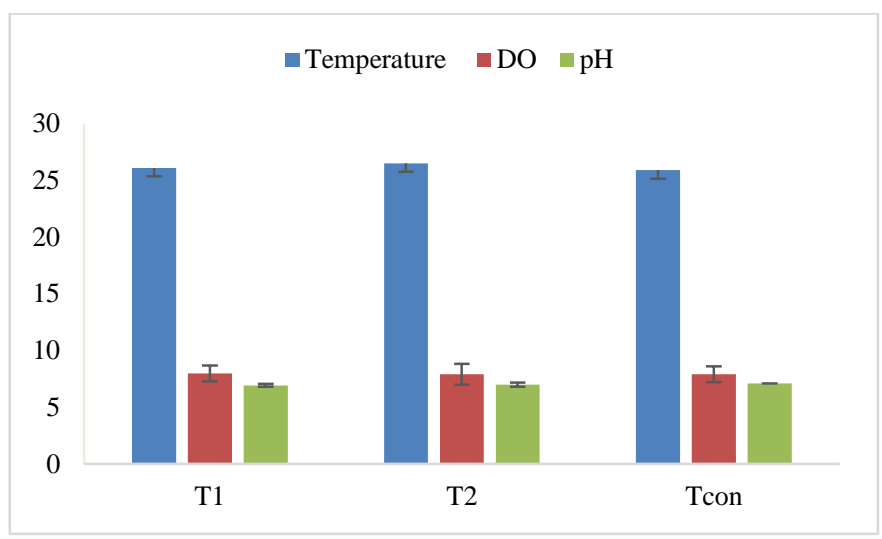

Figure 6. Mean values of temperature, DO and $\mathrm{pH}$ in different treatments during the study period. Vertical bar of each treatment represents standard deviation $( \pm \mathrm{SD})$.

\section{Conclusions}

The present study was conducted with a view to find out a feasible way of producing organic vegetable (tomato) using foliar spray of aspirin from aquaponic system. Firstly it was observed that plant growth and tomato production were higher in $\mathrm{T}_{2}$ (120 ppm aspirin) than $\mathrm{T}_{1}\left(60 \mathrm{ppm}\right.$ aspirin) and $\mathrm{T}_{\text {con }}$ (Control). Secondly, higher aspirin level $(120 \mathrm{ppm})$ in foliar spray reduced the prevalence of disease in tomato plants. This indicates that aspirin has positive impact on tomato production in aquaponic system. Therefore, further research is needed to verify and optimize the aspirin doses at the user level to get representative results.

\section{Conflict of interest}

None to declare.

\section{References}

Cleland FC and A Ajami, 1974. Identification of the flower-inducing factor isolated from aphid honey dew as being salicylic acid. J. Plant Physiol., 54: 904-906.

Cole JC, MW Smith, CJ Penn, BS Cheary and KJ Conaghan, 2016. Nitrogen, phosphorus, calcium, and magnesium applied individually or as a slow release or controlled release fertilizer increase growth and yield and affect macronutrient and micronutrient concentration and content of field-grown tomato plants. Scientia. Hort., 211:420-430.

Cutt JR and DF Klessig, 1992. Salicylic acid in plants a changing perspective. J. Pharma. Technol., 16: 26-34.

Eberhard S, N Doubrava, V Marta, D Mohnen, A Southwick, A Darviell and P Albersheim, 1989. Pectic cell wall fragments regulate tobacco thin-cell layer explant morpho-genesis. Plant Cell., 1: 747-755.

Fariduddin Q, S Hayat and A Ahmad, 2003. Salicylic acid influences net photosynthetic rate, carboxylation efficiency, nitrate reductase activity, and seed yield in Brajuncea jumea. Photosyn. Res., 41:281-284.

Fuentes A, H Youngki, D Park, S Yoon and Y Lee, 2016. Characteristics of tomato plant diseases: A study for tomato plant disease identification, International Symposium on Information Technology Convergence (ISITC). Shanghai, China.

Glazebrook J, 2005. Contrasting mechanisms of defense against biotrophic and necrotrophic pathogens. Ann. Rev. Phytopathol., 43: 205-27.

Goddek S, B Delaide, U Mankasingh, KV Ragnarsdottir, HJijakli and RI Thorarinsdottir, 2015. Challenges of sustainable and commercial aquaponics. Sustainability, 7: 4199-4224.

Gollardo-Collí A, MP Hernandez-Vergara, CI Perez-Rostro and SC Ramirez-Guteirrez, 2014. Biculture tilapia/crayfish in aquaponic system biculture of Tilapia (Oreochromis niloticus) and crayfish (Procambarusa canthophorus) and production of green corn fodder (Zea mays) in an aquaponic system. Glob. Adv. Res. J. Agril. Sci., 3: 233-244.

Heuvelink E, 2005. Tomatoes.CABI, Wallingford, Oxon, UK.

Hooft V, RAM Huljsduijnen, SW Alblas, RHD Rijk and JF Bol, 1986. Induction by SA of pathogenesis-related proteins and resistance to alfalfa mosaic virus infection in various plant species. J. Gen. virol., 67: 2143 2153.

Losanka P, P Tania and U Alexandra, 1997. Salicylic acid: Properties, biosynthesis and physiological role. Bulg. J. Plant physiol., 23: 85-93. 
Losordo TM, MP Massar and J Rakocy, 1998. Recirculating aquaculture tank production systems. An overview of critical considerations. Southern Region Aquaculture Center Publication.

Pallag A, B Pașca, D Gîtea and M Țiț, 2014. The effect of acetylsalicylic acid in physiological processes of Triticumae stivum L., Analele Universităţii din Oradea, Fascicula Protecţia Mediului. pp. 1-23.

Pennazio S, P Roggero and I Gentile, 1985. Effects of salicylate on virus-infected tobacco plants. J. Phytopathol., 114: 203-213.

Quagrainie K, CC Ngugi, S Macharia and KG Mwihaki, 2011. Assessment of integrated pond-cage system for the production of Nile tilapia for improved livelihood of small-scale fish farmers in Kenya. Technical reports of Kenya.

Rahmatullah R, M Das and SM Rahmatullah, 2010. Suitable stocking density of tilapia in an aquaponic system. B. J. Fish. Res., 14: 29-35.

Raskin I, 1992. Role of salicylic acid in plants. Annu. Rev. Plant Physiol. Plant Mol. Biol., 43:439-63.

Roggero P and S Pennazio, 1988. Effects of salicylate on systemic invasion of tobacco plants by various viruses. J. Phytopathol., 123: 207-216.

Singh $\mathrm{G}$ and M Kaur, 1981. Effect of growth regulators on podding land yield of mung bean (Vigna radiate $\mathrm{L}$. Wilczek). J. Plant Physiol., 24:366-370.

USDA, 2019. National Nutrient Database for Standard Reference, Basic Report 11529, Tomatoes, red, ripe, raw, year round average. USA.

Tommonaro G, R Prisco, GR Abbamondi, S Mar-zocco, C Satrnono and N Polia, 2012. Evaluation of antioxidant properties total phenolic content, and biological activities of new tomato hybrids of industrial interest. J. Med. Food., 15: 483-489.

Tyson RV and EH Simonne, 2014. A practical Guide for Aquaponics as an alternative Enterprise. University of Florida Horticulture Sciences Department, UF/IFAS Extension document HS1252.

Vlot AC, DA Dempsey and DF Klessig, 2009. Salicylic acid, a multifaceted hormone to combat disease. Annu. Rev. Phytopathol., 47: 177-206.

White R, 1979. Acetylsalicylic acid (aspirin) induces resistance to tobacco mosaic virus in tobacco. J. Virol., 99:410-412.

White RF, JF Antonlw, JP Carr, RD Woods, 1983. The effects of aspirin and polyactylic acid on the multiplication of TMV in different cultivars of tobacco with and without the N gene. J. Phytopathol., 107: 224-232.

White RF, EP Ryblckl, MB Von Wechmar, JL Dekker and JP Antoniw, 1987. Detection of PR-1 -type proteins in Amaranthaceae, Chenopodiaceae, Graminae and Solanaceae by immune-electro-blotting. J. Gen. Virol., 68: 2043-2048.

Yildiz Y, L Robaina, J Pirhonen, E Mente, D Dominguez, G Parisi, 2017. Fish welfare in aquaponic systems, its relation to water quality with an emphasis on feed and faeces- A review. Water, 9: 1-13.

Zahan S, KMS Rana, MK Islam, T Islam and MA Salam, 2018. Impact of calcium suppliments through egg shell on tomato (Solanum lycopersicum) production in Aquaponic System. Int. J. Appl. Res., 4: 134-139. 